\title{
Understanding Patient Trust in the Athletic Setting through Interviews
}

Shannon L. David

North Dakota State University, shannon.david@ndsu.edu

John H. Hitchcock

Indiana University - Bloomington, jhhitchc@indiana.edu

Follow this and additional works at: https://nsuworks.nova.edu/ijahsp

Part of the Medicine and Health Sciences Commons

\section{Recommended Citation}

David SL, Hitchcock JH. Understanding Patient Trust in the Athletic Setting through Interviews. The Internet Journal of Allied Health Sciences and Practice. 2018 Jan 01;16(2), Article 4.

This Manuscript is brought to you for free and open access by the College of Health Care Sciences at NSUWorks. It has been accepted for inclusion in Internet Journal of Allied Health Sciences and Practice by an authorized editor of NSUWorks. For more information, please contact nsuworks@nova.edu. 


\title{
Understanding Patient Trust in the Athletic Setting through Interviews
}

\begin{abstract}
Trust is a vital component of the patient-clinician relationship yet little is known about trust in the athletic training (AT) profession. Purpose: The purpose of this qualitative study was to define and understand trust in an athletic training setting. Methods: Interviews with Division I student-athlete patients $(n=9)$ and athletic trainers $(n=3)$ were conducted to collect data about participant views and definitions of trust. Data were analyzed using classical and constant comparison techniques; the trustworthiness of findings were assessed via peer debriefing, member checks, and reflexive journaling. Results: The analyses yielded 21 codes and four themes described to promote trust: (1) athletic trainers' attributes, (2) interactions between athletic trainers and athletes, (3) the quality of this relationship and (4) the overall experience. Conclusion: A working definition of trust in the athletic training setting was developed via this work; furthermore, athletic trainers and patients agreed that trust is a complex construct but is vital to developing a productive therapeutic relationship.
\end{abstract}

\section{Author Bio(s)}

Dr. John Hitchcock's area of interest is in evaluating interventions for children with special learning needs, as well as refining research methods for performing such evaluations. He is the director of the Center for Evaluation \& Education Policy and an associate professor of instructional systems technology at Indiana University. He is a former associate editor of School Psychology Review and remains on that journal's editorial board, and co-editor of International Journal of Multiple Research Approaches.

Dr. Shannon David's area of interest is with the patient clinician relationship specifically trust and empathy. Additionally, she is interested in research methods to aid in evaluation of treatment outcomes. She is an athletic trainer and assistant professor at North Dakota State University.

\section{Acknowledgements}

This project was partially funded by the NATAREF Doctoral Grant (212DGP003). 


\title{
TUAHSP \\ The Internet Joưnal of Allied Health Sciences and Practice
}

Dedicated to allied health professional practice and education

Vol. 16 No. 2 ISSN 1540-580X

\section{Understanding Patient Trust in the Collegiate Athletic Training Setting: Findings from Interviews with Patients and Athletic Trainers}

\author{
Shannon L. David, PhD, ATC1 \\ John $\mathrm{H}$. Hitchcock, PhD²
}

1. North Dakota State University

2. Indiana University - Bloomington

United States

\begin{abstract}
Background: Trust is a vital component of the patient-clinician relationship, yet little is known about trust in the athletic training (AT) profession. Purpose: The purpose of this qualitative study was to define and understand trust in a collegiate athletic training setting. Methods: Interviews with Division I student-athlete patients $(n=9)$ and athletic trainers $(n=3)$ were conducted to collect data about participant views and definitions of trust. Data were analyzed using classical and constant comparison techniques; the trustworthiness of findings were assessed via peer debriefing, member checks, and reflexive journaling. Results: The analyses yielded 21 codes and four themes described to promote trust: 1) athletic trainers' attributes, 2) interactions between athletic trainers and athletes, 3) the quality of this relationship, and 4) the overall experience. Conclusion: A working definition of trust in the collegiate athletic training setting was developed via this work. Athletic trainers and patients agreed that trust is a complex construct but is vital to developing a productive therapeutic relationship.
\end{abstract}

\section{INTRODUCTION}

Several studies have established that patient adherence to treatment plans tends to increase as the quality of their relationship with health care providers improves. ${ }^{1-5}$ Health care providers can promote the quality of these relationships by following a patientcentered approach. This approach requires health-care providers to account for patients' feelings and perceived needs. ${ }^{6,7}$ There are five components to the patient-centered approach: 1) explore patient treatment preferences, 2) attempt to understand patients in a holistic manner (e.g., considering their mind, body, and spirit), 3) include a prevention component into each visit, 4) purposefully focus on improving or maintaining a positive relationship with patients, and 5) make intervention approaches as realistic as possible while helping patients see obtainable outcomes. ${ }^{6}$ Overall, the combination of these components should promote trust between health care providers and patients.

The connection between relationship quality, trust, and treatment adherence is also considered via the Primary Provider Theory (PPT). ${ }^{1}$ Supporters of PPT argue that trust is associated with patient adherence ${ }^{1,8}$ Finally, the connection between trust and treatment adherence has been established in multiple physician-based settings. ${ }^{9-11}$ Indeed, trust has been evaluated in other health professions including nursing, psychotherapy, and emergency medicine.14-17 Trust, or lack thereof, can be a critical factor in treatment delivery and participation, and further study of this connection is warranted. ${ }^{12,13}$ Trust and its relationship to treatment adherence (and treatment outcomes) have not, to date, been empirically studied in athletic training (AT) even though others have suggested that the link is worth investigating. ${ }^{12}$ The purpose of this study was, therefore, to develop an initial, working definition of trust in AT, as well as to explore factors that appear to be related to developing a trusting relationship. It is reasonable to expect that the basic connection between trust and the quality of an AT relationship will influence treatment fidelity, just as it does in other healthcare professions. $7,17,18$ 


\section{METHODS}

A flexible and emergent data collection approach that allowed the researcher to follow the respondent's lead was utilized because of the expectation that patient viewpoints about trust would not be easily elicited or readily reduced to a few quantifiable variables. ${ }^{22}$ A series of semi-structured interviews regarding trust were conducted, and analyses were guided by Grounded Theory techniques specifically using classical and constant comparative analyses. ${ }^{19-21}$

\section{Participants}

Twelve participants engaged in semi-structured interviews ( $n=9$ patients; $n=3$ athletic trainers). Patients were recruited through a university listserv, while athletic trainers were recruited through a random sample of emails provided by the National Athletic Trainers' Association. The goal of including both types of study participants was to cross-reference the AT's perceptions of trust with those of patients. For a patient to be included, they were required to be a Division I collegiate athlete and had to have received services from an athletic trainer. Athletic trainers were selected if they provided AT services in a collegiate setting. Respondents were recruited and interviewed until qualitative data saturation-the point at which new information was likely to be redundantcould reasonably be claimed. ${ }^{23,24}$ Guest et al suggest a sample size of 12 is typically adequate for understanding the perceptions of a group in a given context and this general guidance was deemed appropriate for the study. ${ }^{24}$

\section{Procedures}

Interview questions were developed by the first author who has eight years of AT experience, professional licensure and certification, a graduate degree in the field, and who has already completed pilot work on the subject. The first author also had a history of being a collegiate student-athlete who received AT services. The interview questions were developed following general information from Patton including: ask open-ended questions, use jargon that demonstrates experience in the field, distinguish between behaviors, experiences, opinions, values, feelings and emotions, knowledge, and sensory information. ${ }^{22}$ The questions were vetted with a research methodologist who had expertise in interview protocol development and three other experienced, university-affiliated athletic trainers. Probing was used during interviews to develop full explanations of trust and how it influences participants' behavior in AT settings. ${ }^{22}$ Participants, both ATs and patients, were also asked to think out loud about treatment scenarios and their experiences in the past. Interviews were conducted in a private office, were recorded using a digital recorder, and were later transcribed verbatim for analyses in a two-month timeframe. This study was approved by the university institutional review board.

\section{Credibility Techniques}

Five credibility techniques were used in this study. ${ }^{27,28}$ First, level one member checks were used, in which participants reviewed the accuracy of raw transcript data to verify information accuracy. ${ }^{29}$ Three patients and two athletic trainers who completed the interviews were randomly sampled from the participant pool and reviewed their interview transcripts for overall accuracy. No serious errors were noted. Second, two researchers independently analyzed the transcriptions to assess the reliability of thematic development. They demonstrated a high agreement rate. In cases where a minor inconsistency was noted (across approximately $20 \%$ of the themes), reconciliation was easily achieved. Third, findings were shared with other AT experts who were asked to comment on whether statements about trust matched their understanding of theory and if the findings offered reasonable extensions to AT practice. These experts did not question the validity of the findings and saw useful application in promoting a better understanding of AT trust. Fourth, reflexive journaling was conducted by the primary investigator to help account for potential researcher bias, which could yield inaccurate interpretations of interview data. Reflexive journaling is the process through which the primary investigator documents personal thoughts and feelings about specific aspects of the research. ${ }^{27}$ Such reflection is thought to promote the identification and handling of a priori assumptions in an open manner while considering the presented results. Finally, a negative case analyses, which entails a specific search for and accounting of any data that are not consistent with overall results was conducted. ${ }^{27}$ No specific examples of contrary data were found, so this technique was not formally applied.

\section{Data Analyses}

Each interview was transcribed verbatim and analyzed using both classical content (focusing on identifying codes and the number of times they were used in analyses) and constant comparison analyses. ${ }^{30}$ The latter analytic style is a systematic approach used in Grounded Theory, in which open coding is used to collate data into segments and the researcher provides a descriptor (sometimes referred to as "chunks"). ${ }^{19,21}$ This was followed by axial coding that groups these segments into larger themes. Finally, these segments were selectively coded to generate a framework for a theoretical analysis of trust. 19,30 As applied to the current study, such refinement focused on developing a definition of trust. Coding of the transcripts, using the Atlas.ti software (Atlas.ti Americas, Corvallis, OR), was completed by the primary and secondary investigators through label assignment of specific units of data, organizing data into codes, and then into themes. Analyses were interpreted from theory and prior literature, such as literature describing the patient-centered approach.

(c) The Internet Journal of Allied Health Sciences and Practice, 2018 


\section{RESULTS}

Nine Division I collegiate athletes ( $n=4$ females; 5 males; age: $21.89 \pm 2.57$ ) who participated in football, cheerleading, soccer, cross country, basketball, and track and field at the same university were included in the study (Table 1). Three athletic trainers ( $n=2$ males; $n=1$ female; ages: 24, 27, 47) from the private clinic, collegiate, and high school settings were also interviewed.

\begin{tabular}{|l|l|l|l|c|}
\hline \multicolumn{2}{|c|}{ Table 1. Demographics of Interview Participants } & \multicolumn{1}{c|}{ Minimum } & Maximum & Mean \pm SD \\
\hline \multirow{3}{*}{ Patients } & \multicolumn{1}{|c|}{$\begin{array}{l}\text { Number of years playing collegiate } \\
\text { athletics }\end{array}$} & 1 & 5 & $3.11 \pm 1.36$ \\
\cline { 2 - 5 } & Total number of Injuries & 1 & 10 & $3.27 \pm 2.77$ \\
\cline { 2 - 5 } & Most severe pain from an Injury & 6 & 10 & $7.78 \pm 1.5$ \\
\cline { 2 - 5 } & $\begin{array}{l}\text { Longest time spent with an AT on } \\
\text { treatment }\end{array}$ & 1 week & 1 year & $0.311 \pm 2.89$ \\
\hline Athletic Trainers & Years of Experience & 2 & 24 & $10.0 \pm 12.16$ \\
\hline & Age & 24 & 47 & $32.67 \pm 12.5$ \\
\hline
\end{tabular}

\section{Components of a Trusting Relationship}

A total of four themes were summarized from codes and interview data: attributes, relationship, experience, and effort. These themes relate to characteristics the AT either has (e.g., experience) or can control (e.g., effort) when building patient trust. The themes are based on 21 codes with 14 that were a priori in nature, having already been established in other health care professional literature. Seven codes were exploratory having been identified spontaneously during analyses. Table 2 summarizes the themes and codes derived from this study, presents a frequency count of the times a code was identified in the data, sample quotes, and references to associated literature on trust in clinical relationships. For an example, a code that fell within the attributes theme is the athletic trainer's clinical competence, which was used the most often $(n=34)$ during coding, and defined by the researchers during coding as a "belief that the therapist is current (with respect to AT practice) and knowledgeable." Quotes from study participants are provided in the next column (e.g., "...they always know like the names of everything [muscles, tendons, bones], knows what areas and can like describe it ..."). The example supporting the notion that clinical competence is a facet of trust that has been identified by other studies published in the broad medical literature are cited in the last column. A priori codes are denoted with a superscript "a" while exploratory codes are denoted with a superscript "b." 
Table 2. Themes and Codes representing AT Trust

\begin{tabular}{|c|c|c|c|c|c|}
\hline Theme & Code & Frequency & Explanation & Sample Quotes & $\begin{array}{l}\text { Associated } \\
\text { Literature }\end{array}$ \\
\hline Attributes & $\begin{array}{l}\text { Clinically } \\
\text { Competenta }\end{array}$ & 34 & $\begin{array}{l}\text { Belief that the } \\
\text { therapist is } \\
\text { current and } \\
\text { knowledgeable }\end{array}$ & $\begin{array}{l}\text { "...they always know like the } \\
\text { names of everything, knows what } \\
\text { areas and can like point it out and } \\
\text { everything." } \\
\text { "I think um, ya know, the first step } \\
\text { to building a relationship is I would } \\
\text { have to say first and foremost [is] } \\
\text { they have to know what they're } \\
\text { doing." }\end{array}$ & $\begin{array}{l}\text { Aragon et al }{ }^{1} ; \text { Hall } \\
\text { et al }{ }^{3} ; \text { Hupcey \& } \\
\text { Miller }{ }^{35}\end{array}$ \\
\hline Attributes & Attentive $^{a}$ & 20 & $\begin{array}{l}\text { The AT was } \\
\text { described as } \\
\text { being attentive } \\
\text { to needs }\end{array}$ & $\begin{array}{l}\text { "She was attentive to what I } \\
\text { needed and make sure I was } \\
\text { getting it as soon as I could.." }\end{array}$ & Thom et al ${ }^{36}$ \\
\hline Attributes & $\begin{array}{l}\text { Individualized } \\
\text { Care }^{a}\end{array}$ & 21 & $\begin{array}{l}\text { Applying } \\
\text { individualized } \\
\text { professional } \\
\text { knowledge to } \\
\text { develop an } \\
\text { effective } \\
\text { treatment plan }\end{array}$ & $\begin{array}{l}\text { "She would always make sure } \\
\text { everyone was good and like would } \\
\text { go to each and every person in } \\
\text { the training room...just to make } \\
\text { sure no one has anything." }\end{array}$ & $\begin{array}{l}\text { Bova37; Thom \& } \\
\text { Campbell }\end{array}$ \\
\hline Attributes & AT Confidence ${ }^{a}$ & 14 & $\begin{array}{l}\text { ATs appear to } \\
\text { be certain about } \\
\text { his or her } \\
\text { actions }\end{array}$ & $\begin{array}{l}\text { "You could tell they just weren't, } \\
\text { well I guess that goes with } \\
\text { confidence, they weren't really } \\
\text { sure, or you can tell that they } \\
\text { haven't dealt with it before." }\end{array}$ & $\begin{array}{l}\text { Anderson \& } \\
\text { Dedrick }^{17} ; \text { Radwin } \\
\text { et al }^{14}\end{array}$ \\
\hline Attributes & Patience $^{a}$ & 10 & $\begin{array}{l}\text { The AT was } \\
\text { described as } \\
\text { patient when } \\
\text { providing } \\
\text { services }\end{array}$ & $\begin{array}{l}\text { "I think she has a good sense of } \\
\text { patience when working with us." }\end{array}$ & Thom et al $\left.\right|^{36}$ \\
\hline Attributes & Professionalisma & 6 & $\begin{array}{l}\text { Manner in which } \\
\text { the AT conducts } \\
\text { themselves in a } \\
\text { work setting }\end{array}$ & $\begin{array}{l}\text { "I would say there is a level of } \\
\text { professionalism that must be met." }\end{array}$ & \\
\hline Attributes & $\begin{array}{l}\text { Knowledge of } \\
\text { Sportb }^{\text {S }}\end{array}$ & 5 & $\begin{array}{l}\text { Information and } \\
\text { skills directly } \\
\text { related to the } \\
\text { activity }\end{array}$ & $\begin{array}{l}\text { "..if they know a little about the } \\
\text { sport that helps." } \\
\text { "I would say that they should know } \\
\text { the sport cause then they'll have a } \\
\text { better idea of what injuries are } \\
\text { most common and what is } \\
\text { happening on a daily routine [sic]." }\end{array}$ & \\
\hline Attributes & Education $^{b}$ & 2 & $\begin{array}{l}\text { Degree } \\
\text { completed and } \\
\text { status }\end{array}$ & $\begin{array}{l}\text { I know I just needed to be } \\
\text { stretched one time and one of the } \\
\text { umm, undergrad trainers I don't } \\
\text { know what their title is but they } \\
\text { didn't know what to do [because } \\
\text { they are still learning] so level of } \\
\text { education is important." }\end{array}$ & \\
\hline
\end{tabular}




\begin{tabular}{|c|c|c|c|c|c|}
\hline Theme & Code & Frequency & Explanation & Sample Quotes & $\begin{array}{l}\text { Associated } \\
\text { Literature }\end{array}$ \\
\hline Relationship & Communication $^{a}$ & 31 & $\begin{array}{l}\text { An effective } \\
\text { exchange of } \\
\text { information } \\
\text { between the } \\
\text { patient and AT }\end{array}$ & $\begin{array}{l}\text { "You can be really good at } \\
\text { diagnosing things and treating } \\
\text { things but if you're not not very } \\
\text { communicative and you don't } \\
\text { have that relationship, I think, you } \\
\text { could be good at what you do, but } \\
\text { we wouldn't know [sic]." }\end{array}$ & $\begin{array}{l}\text { Aragon et al'; } \\
\text { Bova, } 2006^{37} \\
\text { Safran et al }\end{array}$ \\
\hline \multirow[t]{2}{*}{ Relationship } & $\begin{array}{l}\text { Patient } \\
\text { Educationa }\end{array}$ & 14 & $\begin{array}{l}\text { Providing the } \\
\text { patient with } \\
\text { systematic and } \\
\text { informative } \\
\text { information }\end{array}$ & $\begin{array}{l}\text { "It [educating the patient] eases } \\
\text { you when they explain what they } \\
\text { [athletic trainer] are doing and } \\
\text { why." }\end{array}$ & Bozimowski40 \\
\hline & & & & $\begin{array}{l}\text { "Someone would explain your } \\
\text { injury and explain your body like } \\
\text { why it happened and how it's } \\
\text { going to heal [sic]." }\end{array}$ & \\
\hline Relationship & $\begin{array}{l}\text { Nonverbal } \\
\text { Communicationb }\end{array}$ & 20 & $\begin{array}{l}\text { Process of } \\
\text { receiving } \\
\text { information } \\
\text { through } \\
\text { wordless } \\
\text { message (i.e. } \\
\text { body language) }\end{array}$ & $\begin{array}{l}\text { "It just made sense to me, having } \\
\text { good eye contact and really } \\
\text { listening." }\end{array}$ & $\begin{array}{l}\text { Henry, Fuhrel- } \\
\text { Forbis, Rogers, \& } \\
\text { Eggly, }{ }^{41}\end{array}$ \\
\hline Relationship & Feedback $^{b}$ & 6 & $\begin{array}{l}\text { Encouraging } \\
\text { and targeted } \\
\text { reinforcement }\end{array}$ & $\begin{array}{l}\text { "Positive and encouraging and I } \\
\text { like when they do exercises with } \\
\text { me." }\end{array}$ & \\
\hline Relationship & Approachabilityb & 22 & $\begin{array}{l}\text { Being easy to } \\
\text { talk to and greet }\end{array}$ & $\begin{array}{l}\text { "I think just the fact that they're out } \\
\text { going. I mean they're down to } \\
\text { earth people, they like to joke } \\
\text { around and stuff while you're } \\
\text { getting treatment." } \\
\text { "Be personable with you ya know. } \\
\text { They make it seem like their } \\
\text { people too not just doctors and } \\
\text { their working on you like you're a } \\
\text { piece of machinery or something } \\
\text { [sic]." }\end{array}$ & \\
\hline Relationship & Reputationa & 13 & $\begin{array}{l}\text { Beliefs and } \\
\text { opinions held } \\
\text { about the AT }\end{array}$ & $\begin{array}{l}\text { "Sometimes you get like uh locker } \\
\text { room lawyer type guys, that try } \\
\text { and they're like oh they [AT] don't } \\
\text { know what they're doing." }\end{array}$ & $\begin{array}{l}\text { Mechanic \& } \\
\text { Meyer }^{42}\end{array}$ \\
\hline Relationship & $\begin{array}{l}\text { Personal } \\
\text { Connectiona }\end{array}$ & 39 & $\begin{array}{l}\text { Having a private } \\
\text { and individual } \\
\text { rapport with } \\
\text { each other }\end{array}$ & $\begin{array}{l}\text { "Sometimes it's nice when a } \\
\text { trainer talks to you like [you are] } \\
\text { not just talking to you about } \\
\text { injuries and everything. It's nice to } \\
\text { have normal conversation so it } \\
\text { gives you like a feeling you're still } \\
\text { human." }\end{array}$ & $\begin{array}{l}\text { Alexander \& } \\
\text { Luborsky15; Thom } \\
\text { et al36 }\end{array}$ \\
\hline
\end{tabular}




\begin{tabular}{|c|c|c|c|c|c|}
\hline Theme & Code & Frequency & Explanation & Sample Quotes & $\begin{array}{c}\text { Associated } \\
\text { Literature }\end{array}$ \\
\hline Relationship & Team Worka & 8 & $\begin{array}{l}\text { Working } \\
\text { together to } \\
\text { reach goals }\end{array}$ & $\begin{array}{l}\text { "I think it's great when the AT can } \\
\text { communicate and work with coach } \\
\text { and tell him that he can't go or } \\
\text { whatever." } \\
\text { "I think anytime I need something, } \\
\text { my mother, sometimes she calls } \\
\text { and sometimes my mom has } \\
\text { questions and I can count on her } \\
\text { [athletic trainer] to work with her." }\end{array}$ & $\begin{array}{l}\text { Anderson \& Kaye, } \\
200943\end{array}$ \\
\hline Relationship & Fidelitya & 23 & $\begin{array}{l}\text { Having the } \\
\text { patient's best } \\
\text { interest in mind }\end{array}$ & $\begin{array}{l}\text { "...that they would actually care } \\
\text { and like get me healthy with my } \\
\text { best interest in mind." } \\
\text { "I think if they show interest and } \\
\text { real care about me and } \\
\text { understanding what l'm going } \\
\text { through out there on the court." }\end{array}$ & $\begin{array}{l}\text { Hall et al }{ }^{3} ; \\
\text { Mechanic \& } \\
\text { Schlesinger }{ }^{44}\end{array}$ \\
\hline Relationship & Environment ${ }^{b}$ & 10 & $\begin{array}{l}\text { Atmosphere \& } \\
\text { Resources }\end{array}$ & $\begin{array}{l}\text { "When you walk in there [athletic } \\
\text { training room] the equipment is } \\
\text { new and like the atmosphere is } \\
\text { better than before. It makes me } \\
\text { feel better about coming." } \\
\text { "I really like coming into a clean } \\
\text { [athletic] training room because } \\
\text { like it seems more welcoming or } \\
\text { comforting." }\end{array}$ & \\
\hline Experience & Access $^{a}$ & 31 & Availability of AT & $\begin{array}{l}\text { "Over break if I had something I } \\
\text { could like text her or call her and } \\
\text { she would like response back to } \\
\text { me pretty fast." } \\
\text { "I definitely see a difference in the } \\
\text { AT being available there } \\
\text { throughout the whole day versus } \\
\text { only for a few hours." }\end{array}$ & $\begin{array}{l}\text { Anderson \& } \\
\text { Dedrick }{ }^{17} ; \text { Kao et } \\
\text { al33; Langley \& } \\
\text { Klopper }^{32}\end{array}$ \\
\hline Experience & $\begin{array}{l}\text { Previous } \\
\text { Experiences }\end{array}$ & 8 & $\begin{array}{l}\text { Observation } \\
\text { from an event } \\
\text { that happen } \\
\text { before }\end{array}$ & $\begin{array}{l}\text { "..if I had an injury prior, like if a } \\
\text { trainer diagnosed that to me prior } \\
\text { and how we handled it." }\end{array}$ & $\begin{array}{l}\text { Mechanic \& } \\
\text { Meyer }{ }^{42}\end{array}$ \\
\hline Effort & Patient's Effortb & 11 & $\begin{array}{l}\text { Patient's attempt } \\
\text { with the } \\
\text { treatment }\end{array}$ & $\begin{array}{l}\text { "I think my willingness and effort to } \\
\text { work with my trainer is based on } \\
\text { how much I trust what he is } \\
\text { saying." }\end{array}$ & \\
\hline
\end{tabular}

a a priori code

${ }^{b}$ Exploratory code 
The AT data are also represented in Table 2 because they had similar ideas about how trust could be developed in a clinical relationship. For example, one athletic trainer stated: "I'll initiate communication with them more because good communication skills [and] affective listening I think is number one. You have to be a really good listener." Another athletic trainer discussed the idea of communication but with parents stating, "I feel like good communication with the parents is important because the parents trust you. I had a mom... we were talking about her son who just recently sprained his ankle and... if he was going to be able to play in the game, and she's like I completely trust your decision... even though we had never met... I let her know that [l am] here for the best interest of her child l'm not going to push him further than he needs to be pushed, but at the same time, if he's okay to go, I want him to be able to participate and do that and just kinda[sic] explaining what was going on." These statements were coded as communication, which informed the relationship theme.

Personal connection was cited the most (39 times), followed by clinical competence (34 times), communication (31times), and fidelity (23 times). The codes and their frequency of occurrence are depicted in Table 2. Interestingly, multiple codes also aligned with the five main components of patient centeredness used by physicians. In fact, most of the codes are associated with just one patient-centered component: improving or maintaining a positive relationship with patients. ${ }^{7}$ To have a good trust relationship, the AT must be approachable. The patient must feel comfortable enough to ask for help. As one might expect from theory and common sense, if patients are not able to ask for help because they are uncomfortable or otherwise perceive clinicians as not listening to them, then they are less likely to follow intervention plans.

Other components of the patient centered approach reappeared throughout the codes. As expected, communication often came up on a professional level. However, what was more interesting was personal communication. One participant stated, "You wanna [sic] be able to talk to your [athletic] trainer comfortably whether it's about the injury or not." Personal conversation is a key factor in facilitating a personal connection. Another patient stated, "You can be really good at diagnosing things and treating things but if you're not, ya know, if you're not very communicative and you don't have that relationship I think, I think there's not really a (pause), I don't know, you don't, I think you'd still be good at what you do, but she [the athletic trainer] wouldn't be as trusted [sic]." It appears that a good personal connection can help with approachability as well.

The codes were reasonably mutually exclusive as data captured by one code did not fall easily within another code although there was some overlap. For example, communication and personal connection tend to go hand in hand; it is difficult to build a personal connection without having an effective line of communication. Patients did, however, discuss these issues separately; that is, these were described as distinct components. Communication was described as an exchange of information whereas personal connection was the rapport built in the relationship. One participants stated, "You wanna be able to talk to your [athletic] trainer whether it's about the injury or not (pause) and... if they were like really admit [sic] about not listening to my specific injury that would definitely throw me off." Another participant described personal connection as, "Ya know in the [athletic] training room it's like it's all sport related when I'm in there for the most part and then when l'd see him uptown not so much so it's kinda building that friendship but still being professional about it." Personal communication appeared to be an important characteristic of the patient-clinician relationship.

\section{Exploratory Codes}

While a majority of codes fit well within researcher expectations, existing theory, and literature, there are a few that do not appear to have been previously discussed in the literature. The exploratory codes that did occur were knowledge of sport (5), nonverbal communication (20), feedback (6), approachability (22), patient effort (11), access (31), and environment (10).

An athletic trainer having sport-specific knowledge was important to the patients. One participant also stated, "I would say that they should know the sport cause [sic] then they'll have a better idea of what injuries are most common and what is happening on a daily routine." Having knowledge of the sport allows athletic trainers to make their rehabilitation program sport-specific. Following an injury, it is vital as an athletic trainer to educate patients on their status.

In terms of nonverbal communication, the athletic trainer's body language can influence trust. One athletic trainer stated, "Just having a smile on your face, good body language, um, not having your arms crossed and things like that improved my feeling towards the athletic trainer." Another stated, "I still remember reading it [about body language] and it just resonated so much, it just made sense to me, um good eye contact, uh I think those things tell them that you're listening to them." All three athletic trainers mentioned nonverbal communication.

Feedback during intervention is also important to patients. Providing the patient with positive and informative feedback helps them know what they are doing is correct. One participant mentioned, "I like feedback. To know how I am doing or what I can be doing

(C) The Internet Journal of Allied Health Sciences and Practice, 2018 
better." One athletic trainer stated, "A lot of positive feedback and encouragement and goals to work towards are very helpful [to provide motivation]." Another wrote, "I always try to be positive or encouraging."

The athletic trainer's approachability emerged as another important factor in establishing trust. Approachability can be described as "easy going" and "friendly." One participant wrote, "I think just the fact that they're outgoing. I mean they're down to earth people. They like to joke around and stuff while you're getting treatment." Being approachable can influence a patient's sense of trust. One participant described a time when she felt the athletic trainers were not approachable, "Sometimes, you'll go in there to get your ankles taped or something or they'll just like throw a brace at you and tell you to leave. They don't make an effort with me."

Patient effort was described by the participants as being important. Patients discussed the idea that they need to trust the athletic trainer's advice for them to put in the most effort to their intervention. One patient said, "Ya know whether I trust them will decide whether or not I feel that it's something that I will put all my effort into [sic]." Trust appears to play an important factor into how well the patient adheres to the intervention.

Another exploratory code was athletic trainer access. Access refers to how often athletic trainers are available for their patients. A participant stated, "I definitely see a difference in the athletic trainer being available throughout the whole day versus only for a few hours." The idea of access does not simply mean being in the AT room every minute of the day, but whether or not the patient is able to be in contact with the athletic trainer. For example, one participant said, "Over break, if I had something I could like text her [athletic trainer] or call her and she would like respond back to me pretty fast."

The last exploratory code from the interviews was environment. When the participants discussed environment they referred to having a clean and comfortable AT room. On participant mentioned, "I really like coming into a clean [athletic] training room because like it seems more welcoming or comforting." Patients also discussed atmosphere and resources having an impact on a trusting relationship. A basketball player said, "When you walk in there [AT room] there is brand new equipment this year, and the atmosphere is better than before."

\section{Themes}

Codes were summarized into overall themes. The Attribute theme refers to the education, attentiveness, ability to provide individualized care, patience, and confidence of the AT. Education was an exploratory code within attributes. The athletic trainer's level of education was deemed to be important by the patient. Patients preferred athletic trainers who had a Master's degree over a Bachelor's degree. Patients who did not know that an athletic trainer needs a minimum of a Bachelor's degree and professional certification and licensure were less likely to trust the athletic trainer. Clinicians with more education should have more knowledge, however, the impact of experience was not considered.

The relationship theme addresses how the athletic trainer interacts and works with the patients. Codes that fell within this theme were communication, reputation, and personal connection. An example of a quote describing communication is, "You can be really good at diagnosing things and treating things, but if you're not very communicative and you don't have that relationship, I think you could be good at what you do, but we wouldn't know. Being able to talk to me is really important for me to build my trust." Another example of a relationship pattern was personal connection. One patient stated, "Sometimes it's nice when an [athletic] trainer talks to you not just about injuries. It's nice to have normal conversation so it gives you like [sic] a feeling you're still human."

The experience theme encompasses the familiarity the patient had with the athletic trainer. Two codes represent this theme: 1) access and 2) previous experience. A quote from a patient related to access was, "I definitely see a difference in the athletic trainer being available there, at practice or in the AT room, throughout the whole day versus only for a few hours. That way I knew I could get their help if I needed it." Another quote to explain previous experience was, "...if I had the same injury prior, like if the [athletic] trainer diagnosed that to $\mathrm{me}[\mathrm{sic}]$ prior and how we handled it."

The final theme that emerged was effort. Effort can be described as the patient's effort towards the prescribed treatment. An example of this theme is as follows "I think my willingness and effort to work with my [athletic] trainer is based on how much I trust what he is saying."

\section{Athletic Trainer Patients' Definition of Trust}

Participants had difficulty defining and discussing trust which, in part, justified the methodological approach and analyses used in this study. Participant 6, for example, stated, "And I would say trust in general is like (pause), um (pause) oh man (pause), I don't even know how to define trust honestly." Other respondents hesitated, were vague, and sometimes used platitudes, suggesting they have not previously thought about the topic. One participant further illustrated this point because he went to extremes to

(c) The Internet Journal of Allied Health Sciences and Practice, 2018 
describe trust, and yet another participant was unable to define trust but rather stated some of its components (Table 3). This is evidence that respondents did not come to the interview with ready-made answers and used stark or extreme phrasing when trying to communicate the abstract idea. Unfortunately, an inability to define the construct as applied to AT in this study may undermine a capacity to account for it in future studies. What could be gleaned from the data was patients referenced the notion that trust entails a sense of confidence in an AT, which was viewed as a type of feeling. Other terms that were used to describe trust were: understanding, communication, reliability, and knowledge of the athletic trainer.

Table 3. Trust Described During Interviews

\begin{tabular}{|c|c|}
\hline Participant & Description \\
\hline 1 & $\begin{array}{l}\text { "Well I think in this situation it's (pause) knowing that what you're doing is going to get you back on } \\
\text { the field and at least to the point where you were before if not better." }\end{array}$ \\
\hline 2 & $\begin{array}{l}\text { "I would say it just means um the ability to know that their gunna [sic] give you the best treatment } \\
\text { to get you healthy again. It kinda [sic] goes with knowledge in this context. (pause) That they're } \\
\text { going to give you the best treatment." }\end{array}$ \\
\hline 3 & $\begin{array}{l}\text { "[l] guess kinda [sic] like believing (pause) what their telling you what you to do and putting like } \\
\text { you're state of well-being in their hands." }\end{array}$ \\
\hline 4 & $\begin{array}{l}\text { "Um, I would say it would just be uhh like being able to like follow what someone says and like } \\
\text { understanding what their saying and um, trying to think of a good word to use. Uh, it's just like } \\
\text { (pause) having a connection I guess like even a connection with them so you can um, (long pause) } \\
\text { just under, just understanding [sic]." }\end{array}$ \\
\hline 5 & $\begin{array}{l}\text { "It deals with like believing in them. Kind of trust like you know based on what they've done in the } \\
\text { past to you or other athletes like maybe like their past history like that will cause you to trust } \\
\text { someone a lot more than if you just meet someone out of nowhere and don't really know what } \\
\text { they've been doing or if they're new." }\end{array}$ \\
\hline 6 & $\begin{array}{l}\text { "I would say well person to person I would say having a general understanding of each other, } \\
\text { knowing where things are and um (pause), being able knowing that uhh, the opposite person has } \\
\text { your back regardless of whatever is going on. Oh yeah I think um,(pause) I definitely think it's a } \\
\text { belief... it's a belief and attitude, but l'm not sure what kind of belief or attitude it is." }\end{array}$ \\
\hline 7 & "I feel like she knows what she's talking about and she's gunna [sic] make my injury go away." \\
\hline 8 & $\begin{array}{l}\text { "I think it's knowing that no matter what somebody says to you to believe in that and obviously if } \\
\text { somebody tells you to go jump off a bridge that's I mean there's some reasoning in that." }\end{array}$ \\
\hline 9 & $\begin{array}{l}\text { "In the in the relation just I mean in the uh, believing in what they're saying, believe in the message } \\
\text { that they convey to you, how's that not what they say the message because you have to believe in } \\
\text { the facial experiences um, and gosh that's so hard." }\end{array}$ \\
\hline 10 & "Just reliability and um knowing that I can count on them to get the job done right and to." \\
\hline 11 & $\begin{array}{l}\text { "I think it's a feeling um or the ability to unconsciously rely on an individual for really any particular } \\
\text { reason." }\end{array}$ \\
\hline 12 & $\begin{array}{l}\text { "Umm, you know I don't know if I can explain it...Gosh that really is a tough one. Is it a feeling or a } \\
\text { belief? I'm not entirely sure. I guess it could mean being reliable but umm, it's more than that. I } \\
\text { don't know." }\end{array}$ \\
\hline
\end{tabular}

*Note that participant 12 was unable to clearly describe or define trust. He made suggestions of components but was unable to articulate a definition. 
From this information, in the context of athletic training, trust was defined as a belief (and/or a feeling) that an athletic trainer has the patient's best interest in mind and that treatment and any associated information provided during treatment, will help the patient return to activity. Patient trust is informed in part by their perception of their athletic trainer's attributes (e.g., education, patience, confidence), level of effort, experience, and relationship skills.

\section{DISCUSSION}

A key contribution of this work to the AT literature is predicated on the idea that constructs that are difficult to define and describe are likely to be difficult to measure and ultimately influence. This is true of the trust construct, yet there is merit in understanding it better within AT given its role in clinician-athlete relationships and likely connection to later treatment fidelity. The current study's results revealed that trust has both an emotional component (approachability, fidelity, etc.) as well as a cognitive component (providing feedback, patient education, etc.). The two components have been described before to explain the patient-clinician relationship. ${ }^{6}$ However, it appears that both are also components critical to first establish trust and then to further develop the patient-clinician relationship. It is important to recognize that the emotional and cognitive components are not mutually exclusive and can affect each other. For example, consider the codes communication and personal connection. Although participants described them as separate ideas, they overlap, and when considered together, may have a synergistic effect on improving ATpatient relationships. Kelley et al ${ }^{6}$ describe a similar idea after a detailed systematic review and meta-analysis of randomized controlled trials that examine the connection between this type of relationship and health outcomes. This meta-analysis revealed a small, but statistically significant, result suggesting that the patient-clinician relationship does influence patient outcomes. ${ }^{6}$ This finding has bearing on the current study because it demonstrates a connection between trust and AT-patient relationships.

This qualitative study also revealed facets of trust not previously described in the AT literature. The level of AT education may be an important factor. Interview responses suggest that athletic trainers should communicate their overall and sport-specific experiences with patients to build trust. Providing unique qualities or experiences can show patients that the athletic trainer's knowledge has prepared them for the particular job. A good time to describe qualifications or related previous experience could be during the initial meeting session with teams. In addition, athletic trainers need to be conscious of their nonverbal communication and its effect on the patient-clinician relationship; a positive body language can help facilitate a good patient-clinician relationship. Examples of positive body language include making eye contact, facing the patient, and nodding in agreement at the appropriate times.

Although communication is a well-known facet of trust, this work serves as a reminder of the need for athletic trainers to educate patients on their status. Not only is this useful to help patients understand their conditions, but it also reveals that the athletic trainer is knowledgeable. Providing a description of the injury and purpose of the treatment plan shows that the athletic trainer has carefully thought about the individual.

Access was another important aspect to establish trust and has been discussed previously in other health care professions. ${ }^{17,32,33}$ Because AT has its own unique attributes, there are a variety of tasks the athletic trainers can do to improve access. Providing the patients with a phone number to text or email address provides easier and faster access to their care. This will allow immediate access and help build the relationship.

Environment also appeared as an important aspect to build a trusting relationship. Environment has been discussed previously by Norkfolk et al but to establish empathy rather than promote trust. ${ }^{34}$ Environmental factors considered previously have been waiting room size, lighting, and layout, whereas in this study, it was also considered equipment and cleanliness. ${ }^{34}$ Having a clean AT room with newer equipment appears to provide a sense of comfort and a good atmosphere that can influence the amount of trust a patient has for their athletic trainer. This may or may not be an aspect of trust that the athletic trainer has any control over, but it may impact the relationship. However, an athletic trainer can have control over equipment organization and cleanliness.

Providing quality feedback was another important aspect. Although not specifically related to trust, positive feedback has been shown to increase levels of performance when completing a given task. ${ }^{29}$ To continue to improve the patient-clinician relationship, it is key to provide positive and informative feedback during treatment. For example, during rehabilitation rather than simply saying "Good job," the athletic trainer can say, "Good job, your technique during that exercise is spot on."

This work has helped to highlight the importance of trust in the athletic trainer-patient relationship and has provided constructs AT's should consider when promoting a sense of trust in their practice.

(c) The Internet Journal of Allied Health Sciences and Practice, 2018 


\section{Delimitations and Limitations}

This study was delimited to Division I collegiate-aged participants; therefore, findings from this study cannot be readily applied outside of this population. In terms of limitations, the authors worked under the assumption that data saturation was achieved. However, it is possible that there is additional information that may have been missed. This study is also limited by its small sample size, which is often a byproduct of managing transcribed interview data and imposing a data collection burden on participants. Future research examining the construct of trust and the related codes and themes in other age groups as well as other AT settings (e.g., secondary setting, industrial setting, etc.) would be beneficial as it is unclear how this information generalizes to other age groups and AT settings.

\section{Conclusion}

The purpose of this study was to develop a definition of trust in AT and explore factors that appear to be related to developing a trusting relationship. Four themes, attributes, relationship, experience, and effort, emerged to help understand how trust influences the relationship between the athletic trainer and patient. Additionally, a working definition of trust between athletic trainers and patient was developed. Athletic trainers can use this information to help improve their relationships and potentially improve patient adherence.

\section{REFERENCES}

1. Aragon S, McGuinn L, Bavin S, Gesell S. Does pediatric patient-centeredness affect family trust? J Healthc Qual. 2010;32(3):23-31. doi: 10.1111/j.1945-1474.2010.00092.x. [PMID: 20500777]

2. Golin CE, DiMatteo MR, Gelberg L. The role of patient participation in the doctor visit. Implications for adherence to diabetes care. Diabetes Care. 1996;19(10):1153-64. [PMID: 8886566]

3. Hall MA, Dugan E, Zheng B, Mishra AK. Trust in physicians and medical institutions: What is it, can it be measured, and does it matter? Milbank Q. 2001;79(4):613-39. [PMID: 11789119]

4. Schulman B. Active patient orientation and outcomes in hypertensive treatment: Application of a socio-organizational perspective. Med Care. 1979;17(3):267-80. [PMID: 763004]

5. Tresolini CP, Pew-Fetzer Task Force. Health Professions Education and Relationship-Centered Care. San Francisco, CA: Pew Health Professions Commission, 1994.

6. Kelley JM, Kraft-Todd G, Schapira L, Kossowsky J, Riess H. The influence of the patient-clinician relationship on healthcare outcomes: A systematic review and meta-analysis of randomized controlled trials. PLoS ONE. 2014;9(4):e94207. doi: 10.1371/journal.pone.0094207. [PMID: 24718585]

7. Stewart M, Brown JB, Donner A, McWhinney IR, Oates J, et al. The impact of patient-centered care on outcomes. J Fam Prac. 2000;49(9):796-804. [PMID: 11032203]

8. Aragon, S. The Primary Provider Theory. Available at: www.ceehd.com/index.php?option=com_content\&task=view\&id=10\&ltemsid=16. Accessed February 13, 2016.

9. Greenfield S, Kaplan SH, Ware JE Jr, Yano EM, Frank HJ. Patients' participation in medical care: Effects on blood sugar control and quality of life in diabetes. J Gen Intern Med. 1988;3(5):448-57. [PMID: 3049968]

10. Mahler HI, Kulik JA. Preferences for health care involvement, perceived control and surgical recovery: a prospective study. Soc Sci Med. 1990;31(7):743-51 [PMID: 2244216]

11. Lee YY, Lin JL. The effects of trust in physician on self-efficacy, adherence, and diabetes outcomes. Soc Sci Med. 2009;68(6):1060-8. [PMID: 19162386]

12. Myer NL, Capilouto GJ. A model for rehabilitation adherence in athletes demonstrating different attachment styles. Int $J$ Athl Ther Train. 2016;21(4):12-7.

13. Schneider IK, Konijn EA, Righetti F, Rusbult CE. A healthy dose of trust: The relationship between interpersonal trust and health. Personal Relationships. 2011;18(4):668-76.

14. Radwin LE, Washko M, Suchy KA, Tyman K. Development and pilot testing of four desired health outcome scales. Oncol Nurs Forum. 2005;32(1):92-6. [PMID: 15660147]

15. Alexander LB, Luborsky L. The penn helping alliance scales. In Greenberg LS, Pinsof WM (Eds), The Psychotherapeutic Process: A research handbook. New York, NY: Guilford Press, 1986.

16. Pearson SD, Raeke LH. Patients' Trust in physicians: Many theories, few measures, and little data. J Gen Intern Me. 2000;15(7):509-13. [PMID: 10940139]

17. Anderson L, Dedrick R. Development of the trust in physician scale: A measure to assess interpersonal trust inpatient-physician relationships. Psychological Reports. 1990;67(3):1091-100. [PMID: 2084735]

18. Dwyer D, Liu Hong, Rizzo JA. Does patient trust promote better care? Applied Economics. 2012;44:2283-95.

19. Glaser BG, Strauss AL. The Discovery of Grounded Theory: Strategies for qualitative research. Chicago: Aldine, 1967.

20. Strauss A. Qualitative Analysis for Social Scientists. Cambridge, United Kingdom: University of Cambridge Press, 1987. 
21. Strauss A, Corbin J. Basics of Qualitative Research: Techniques and procedures for developing grounded theory. Thousand Oaks, CA: Sage, 1998.

22. Patton M. Qualitative Research and Evaluation Methods. Thousand Oaks, CA: Sage, 2015.

23. Charmaz K. Constructing Grounded Theory: A practical guide through qualitative analysis. Sage. Thousand Oaks, CA, 2006.

24. Guest G, Bunce A, Johnson L. How many interviews are enough? An experiment with data saturation and variability. Field Methods. 2006;18(1):59-82.

25. Mason M. Sample size and saturation in PhD studies using qualitative interviews. Forum: Qualitative Social Research. Available at: http://www.qualitative research.net/index.php/fqs/article/viewarticle /1428/3027\#g12. Updated 2010. Accessed November 29, 2016.

26. Willis GB. Cognitive Interviewing: A tool for improving questionnaire design. Thousand Oaks, CA: Sage, 2005.

27. Nastasi BK, Schensul SL. Contributions of qualitative research to the validity of intervention research, J Sch Psychol. 2005;43(3):177-95.

28. Patton MQ. Enhancing the quality and credibility of qualitative analysis. Health Services $\quad$ Research. 1999;35(5):1189208.

29. Brantlinger E, Jimenez R, Klingner J, Pugach M, Richardson V. Qualitative studies in special education. Exceptional Children. 2005;71(2):195-207.

30. Leech N, Onwuegbuzie AJ. Qualitative data analysis: A compendium of techniques and a framework for selection for school psychology research and beyond. Sch Psychol Q. 2008;23(4):587-604.

31. Di Blasi Z, Harkness E, Ernst E, Georgiu A, Kleijnen J. Influence of context effects on health outcomes. A systematic review. Lancet. 2001;357:757-62. [PMID: 11253970]

32. Langley GC, Klopper $\mathrm{H}$. Trust as a foundation for the therapeutic intervention for patients with borderline personality disorder. J Psychiatr Ment Health Nurs. 2005;12(1):23-32. [PMID: 15720494]

33. Kao A, Green DC, Davis NA, Koplan JP, Cleary D. Patients' trust in their physicians: Effects of choice, continuity, and payment method. J Gen Intern Med.1998;13(10):681-6. [PMID: 1500897]

34. Norfolk T, Birdi K, Walsh D. The role of empathy in establishing rapport in the consultation: A new model. Med Edu. 2007;41:690-7. doi: 10.1111/j.1365-2923.2007.02789.x. [PMID: 17614890]

35. Hupcey JE, Miller J. Community dwelling adults' perception of interpersonal trust vs. trust in health care providers. Patient Experience. 2005;15(9):1132-1139. [PMID: 16911054]

36. Thom DH, Wong ST, Guzman D, Wu A, Penko J, et al. Physician trust in the patient: Development and validation of a new measure. Ann Fam Med. 2011;9(2):148-54. doi: 10.1370/afm.1224. [PMID: 21403142]

37. Bova C, Fennie KP, Watrous E, Dieckhaus K, Williams AB. The health care relationship (HCR) trust scale: Development and psychometric evaluation. Res Nurs Health. 2006;29(5):477-88. doi: 10.1002/nur.20158. PMID: 16977644

38. Thom DH, Campbell B. Patient-physician trust: An exploratory study. J Fam Prac. 1997;44(2):169-76.

39. Safran DG, Kosinski MA, Tarlov AR, Rodgers W, Taira D, et al. The primary care assessment survey: Tests of data quality and measure performance. Med Care. 1998;36(5):728-39. [PMID: 9596063]

40. Bozimowski, G. Patient perceptions of pain management therapy: A comparison of real-time assessment of patient education and satisfaction and registered nurse perceptions. Pain Manag Nurs. 2012;13(4):186-93. [PMID: 23158700]

41. Henry SG, Fuhrel-Forbis A, Rogers MA, Eggly S. Association between nonverbal communication during clinical interactions and outcomes: A systematic review and meta-analysis. Patient Educ Couns. 2012;86(3):297-315. doi: 10.1016/j.pec.2011.07.006. [PMID: 21824738]

42. Mechanic D, Meyer S. Concepts of trust among patients with serious illness. Soc Sci Med. 2000;51:657-68. [PMID: 10975226]

43. Anderson DJ, Kaye KS. Staphylococcal surgical site infections. Infect Dis Clin North Am. 2009;23:53-72. doi: 10.1016/j.idc.2008.10.004

44. Mechanic $D$, Schlesinger $M$. The impact of managed care on patients' trust in medical care and their physicians. JAMA. 1996;275(21):1693-7. doi:10.1001/jama.1996.03530450083048. [PMID: 8637148] 